\title{
Bazı Ekmeklik Buğday (Triticum aestivum L.) Çeşitlerinin Kalite Potansiyelleri ve Beslenme Fizyolojisi Açısından Önemi
}

\author{
*Osman EREKUL ${ }^{1}$ Ali YiĞìT¹ Yakup Onur KOCA ${ }^{1} \quad$ Frank ELLMER ${ }^{2}$ Kirsten WEIB ${ }^{2}$
}

\author{
${ }^{1}$ Adnan Menderes Üniversitesi, Ziraat Fakültesi, Tarla Bitkileri Bölümü, Aydın-Türkiye \\ ${ }^{2}$ Humboldt Üniversitesi, Yaşam Bilimleri Fakültesi, Albrecht Daniel Thaer Enstitüsü, Berlin-Almanya \\ *Sorumlu yazar e-posta (Corresponding author; e-mail): oerekul@adu.edu.tr
}

\section{Öz}

Dünya'da ve ülkemizde tarımsal üretimde ilk sırada yer alan ekmeklik buğday (Triticum aestivum L.) başta insan beslenmesinde önemini korumaktadır. Çalışmamızda Ege Bölgesinde ve ülkemizin farklı ekolojik koşullarında yetiştirilen 15 adet ekmeklik buğday çeşidine yönelik kalite potansiyellerinin ortaya konulması amacıyla ekmeklik kalite özellikleri, hamur özellikleri ile beslenme fizyolojisi açısından özellikler incelenmiştir. Bazı sonuçlara göre protein içeriklerinin \%10.7-18.7, nişasta miktarlarının \%56.4-65.2, gluten miktarlarının \%26.7-33.5, sedimantasyon miktarlarının 19-31 ml, düşme sayısının 283-404 s ve su alma oranlarının ise \%58.8-69.3 arasında değişim gösterdiği saptanmıştır. Çeşitlere ait ve DPPH radikali yöntemine göre yapılan toplam antioksidan aktivite içerikleri ise \%11.89-26.33 arasında değişmiştir. Kükürtlü aminoasitler olan metiyonin aminoasidin içeriği 0.22-0.37 g/100 g un arasında, sistin aminoasidin içeriği ise 0.494-0.706 g/100 g un arasında değişmiştir. Sonuçlar değerlendirildiğinde, çeşitler arasında istatistiksel anlamda yüksek düzeyde önemli farklılıklar bulunmuştur. Yapılan çalışma ile ülkemizde yaygın olarak yetiştirilen ekmeklik buğday çeşitlerin kalite potansiyelleri ve beslenme fizyolojisi bakımından önemi ortaya konulmaktadır, ayrıca ileride yapılacak kalite ve ıslah çalışmalarında incelenen özelliklerinde göz önüne alınması hedeflenmiştir.

Anahtar Kelimeler: Ekmeklik buğday, kalite, antioksidan, amino asit

\section{Quality Potantials and Importance in Terms of Nutrition Physiology of Some Bread Wheat (Triticum aestivum L.) Varieties}

\begin{abstract}
Bread wheat (Triticum aestivum L.) ranks first in agricultural production in the world and our country that remains particularly important in human nourishment. In this study, bread making quality, dough properties and nutritional physiology features were examined in order to determine quality potentials of 15 bread wheat varieties which are grown in Aegean region and different ecological conditions in Turkey. According to obtained results; protein content 10.7-18.7\%, starch amount 56.4-65.2\%, gluten content 26.7-33.5\%, sedimentation amount $19-31 \mathrm{ml}$, falling number 283-404 $\mathrm{s}$ and water absorption rate \%58.8-69.3 values were obtained from analyzed parameters. Total antioxidant activity analyzed due to DPPH radical scavenging method and values of varieties changed between $11.89-26.33 \%$. Besides the results obtained from sulphurous aminoacids ranged between methionine 0.22-0.37 g/100 g and cystine 0.494-0.706 g/100 g in whole grain flour. In terms of this study, importance of quality potentials and nutrition physiology of bread wheat varieties which are commonly grown in our country is revealed also it is aimed that considering the features examined in this study for quality and breeding studies in the future.
\end{abstract}

Keywords: Bread wheat, quality, antioxidant, amino acid

\section{Giriş}

$\mathrm{D}$ ünya'da insanların beslenmesinde ilk sıralarda yer alan buğday kültür bitkisi 2012 yılı verilerine göre yaklaşık 216 milyon hektar ile tahıllar içerisinde en fazla ekim alanına sahip olmuştur. Son on yıl içerisinde (2003-2012) dünyada buğday ekim alanı 207 ile 216 milyon hektar arasında değişiklik göstermiştir, üretim bakımından ise son 5 yıl içerisinde artan dünya verim ortalamasına bağlı olarak üretimde artışlar yaşanmıştır. Buğday üretim bakımından ise mısır ve çeltikten sonra 674 milyon ton ile üçüncü sırada yer almıştır. Türkiye dünya buğday ekim alanı içerisinde yıllar arasında değişmekle birlikte \%3 ile 3.5 
arasında bir paya sahip olup dünyada ilk on ülke arasında yer almaktadır. Ülkemizde buğday ekim alanı 2012 yılı itibariyle nadas alanları hariç 19.6 milyon hektar olan toplam tarım arazileri içerisinde 7.5 milyon hektarlık bir alan ile \%38.2'lik bir paya sahip olarak ülkemiz tarım alanların ekilişinde en önemli paya sahiptir. 1998 yılından günümüze buğday ekim alanlarında azalmalar yaşanmaktadır, ancak bu azalmaların yanında sınırlıda olsa verimde yaşanan artışlar sebebiyle buğday üretiminde 2012 yılına kadar ciddi bir düşüş meydana gelmemiştir. Ancak ülkemizde devam etmesi beklenen nüfus artışı, değişen iklim koşulları ve üretimin monokültür ve/veya kısıtlı sürdürülebilir tarım uygulamaları çerçevesinde yürütülmesi nedeniyle önümüzdeki yıllarda buğday tarımında öncelikli hedefin birim alandaki tane verimin arttırımasına yönelik çeşitlerin geliştirilmesi ve buğday yetiştiriciliğine yönelik etkin tarımsal uygulamaların yerine getirilmesi olacaktır. Ancak yine üretimin arttırılmasıyla birlikte kaliteli buğday ürünün elde edilmesi ve geliştirilmesi birlikte düşünülmeli ve göz ardı edilmemelidir. Buğday kültür bitkisinin kullanım amacının dikkate alınarak yetiştiriciliğine yön verilmesi elde edilecek kalitenin belirlenmesi açısından büyük önem arz etmektedir. Tane veriminde olduğu gibi bir buğday genotipin ürün kalitesi çimlenme ve sarı olum dönemi arasında geçen uzun bir sürenin içerisindeki büyüme ve gelişme olaylarından ve bunların karşılıklı ilişkilerinden önemli düzeyde etkilenmektedir ve buna bağlı olarak şekillenmektedir. Verim bakımından olumsuz giden gelişmeler bazen birçok veya bazı kalite özelliklerin daha iyi sonuçlar vermesine neden de olabilmektedir. Bu yüzden serin iklim tahıllarında ürün kalitesi değerlendirildiğinde tohum ekiminden hasadına kadar büyüme ve gelişme aşamalarında verimi meydana getiren verim öğelerin hangi gelişme dönemlerinde şekillendikleri, potansiyelleri ve verim öğeleri arasındaki karşılıklı etkileşimlerinin iyi bilinmesi gerekmektedir. Zira ürün kalitesinde meydana gelen farklılıklar çoğu zaman bu etkileşimlerin bir sonucu olarak ortaya çıkmaktadır. Verim öğeleri arasındaki karşılıklı etkileşimlerin temelinde çeşitlerin kalıtsal özelliklerin yanı sıra iklim ve toprak özellikleri bulunmaktadır. Hatta aynı coğrafi bölge içerisinde iklim ve toprak özellikleri büyük farklılıklar gösterebilmektedir. Beslenmesi ağırlıklı olarak buğdaya dayalı ülkelerin buğday yönünden kendine yeterli olması ve stoklarında yeterince buğday ürünü bulundurması stratejik bir önem arz etmektedir. Özellikle son yıllarda buğday insan ve hayvan beslenmesinin yanında enerji üretimine (termik, bioetanol ve biogaz kullanımı) yönelik kullanım taleplerinin artması gelecekte buğday üretimini daha da değerli bir noktaya taşıyacaktır.

Daha yüksek bir üretim için tane verimin artırılması gerekse de insan ve hayvanların daha sağlıklı gıdalara ulaşmaları konusunda da son yıllarda sağlıklı ve kaliteli buğdayların üretilmesine yönelik talep ve bu konudaki bilinçlenme artmıştır. Yıllardır öncelikli tane verim artışına yönelik yapılan ıslah çalışmaları kalite konusunun arka planda bırakmış bu durum ise buğday üreticilerin ürünlerini pazarlamada ve işlemede kalite ile ilgili çok sayıda sıkıntılar yaşamasına neden olmuştur. Buğday kalite potansiyelinin ortaya çıkmasında genotip, agronomik ve kültürel işlemler ile çevrenin ve bunların karşılıklı etkileşimlerinin etkili olduğu bilinmektedir (Erekul ve ark. 2009). Günümüzde un ve unlu mamuller teknolojisinin ve endüstrisinin gelişmesi, belirli kalite ve nitelikte olan buğdaylara gereksinimi arttırmıştır. Kaliteli buğday açığı, üretim yapan firmaların ürünlerini işlemede, depolamada ve pazarlamada ciddi sıkıntılara yol açmaktadır. Bu nedenle buğday ıslahında sadece tane verimi ve verim öğelerine göre seçim yapılmamalı buğday üretimindeki kalite açığını kapatabilecek çeşitler geliştirilmeli ve bu çeşitlerin kalite potansiyellerini ortaya koyan araştırmalar yapılmalıdır.

Buğdayın işlenerek ürün elde edilmesinde içerdiği protein miktarı ve kalitesi en fazla dikkate alınan kalite özelliklerinden biridir. Buğdayların protein içeriği çeşide ve yetiştirme dönemi esnasındaki çevresel faktörlere bağlı olarak \%6-22 arasında büyük bir değişim gösterebilmektedir. Böylesine geniş aralıklarda protein miktarı değişiminin görülmesi ülkemizde yaygın olarak yetiştirilen buğday çeşitlerinin protein potansiyel içeriklerinin belirlenmesi son derece önemlidir. Beslenme ile alınan protein; vücudun gelişimini düzenleyen, onarımını, bakımı ve dokuların yenilenmesi için gerekli proteinin yapıtaşları olan aminoasitleri sağlamaktadır. Beslenme bakımından büyük öneme sahip esansiyel aminoasitler toplam protein içeriğinden etkilenmektedir. İnsan vücudunda sentezlenemeyen esansiyel aminoasitlerin yeterli miktarda günlük beslenme ile alınması gerekmektedir (Anjum et al. 2005). Günümüzde insanların artık yeterli beslenme 
değil yaşamlarını devam ettirebilmeleri için sağııklarını korumaya da intiyaçları vardır. Bu nedenle vücudun hastalıklara yakalanma riskini azaltıcı bağışıklık sisteminin güçlenmesi ve bu şekilde korunması için sağlıklı ve güvenilir gıdaların tüketilmesi gerekmektedir. Buğday ve ürünlerinin sadece insanların beslenmesindeki yeri ve önemi değil buğday tanelerin içerdikleri insan sağığına katkıda bulunan ve korunmasına yardımcı olan yararlı maddeler nedeniyle de birçok ölümcül hastalık riskini azaltıcı ve önleyici etkilerinin bulunduğu bilinmektedir (Ryan et al. 2011). Son yıllarda hastalıklara yakalanma risklerini azaltıcı, insan sağlığını koruyucu fenolik madde ve antioksidan içerikli gıdalardan bahsedilmektedir. Budayın içerdiği fitokimyasal maddeler (fenolik bileşikler, karotenoidler ve $\mathrm{E}$ vitamini) nedeniyle doğal besinsel antioksidan kaynağıdır ve bu aktif bileşikler güçlü antioksidan aktiviteleri ile insan ve hayvanlarda birçok kronik rahatsızlığı önler veya ilerlemesini geciktirebilmektedir (Menteş-Yılmaz 2011). İnsan ve hayvanların beslenmesinde değerli besinler daha çok buğday tanesinin dış kısımlarında bulunmaktadır özellikle de Aleuron tabakasında. Aleuron tabakasında yer alan proteinler (Albumin ve Globulin) tanedeki toplam proteinin yaklaşık \%20 sini oluşturmaktadır ve gluten proteinlerinden farklı yapı özelliklerine sahiptir. Aleuron tabakasındaki bu proteinler viskoelastik özelliklere sahip değildir ve böylece hamur oluşumunda görev almazlar, ancak beslenme fizyolojisi açısından önemlidir.

Buğday tanesi karbonhidrat, protein mineral maddeler, iz elementleri, vitaminler, yağ asitleri ile sekonder bitki metabolitleri olarak adlandırılan renk maddeleri ve fenoller bakımından zengindir. Besin maddeleri buğday tanesinin farklı kısımlarında bulunmasından dolayı buğday tanesi ne kadar fazla kabuk kısmına doğru öğütülürse ve un randımanı arttırılırsa elde edilen ürünler o oranda beslenme fizyolojisi bakımından zenginleşmektedir.

\section{Materyal ve Yöntem}

Çalışmamızda Ege Bölgesinde ve ülkemizin farklı ekolojik koşullarında yetiştirilen 15 adet ekmeklik buğday çeşidine yönelik kalite potansiyellerinin ortaya konulması amacıyla ekmeklik kalite özellikleri, hamur özellikleri ve beslenme fizyolojisi acısından özellikler incelenmiştir.
Çeşitlerin protein oranları hem NIRS (Near Infrared Reflectance Spectroscopy) hem de Dumas metoduna göre Elementar Max CN cihazlarında ölçümleri yapılmıştır. Nişasta analizleri ise NIRS metoduna göre gerçekleştirilmiştir.

Çeşitlerin hamur özelliklerini değerlendirmek amacıyla çeşitlerden elde edilen unların su kalmadırma oranları Farinograf cihazıyla ICC (International Association for Cereal Chemistry) Standart No: $115 / 1$ 'de verilen yönteme göre iki tekrarlamalı ve ortalaması alınarak saptanmıştır.

Sedimentasyon değeri ICC-Standart No: 116/1'e göre belirlenmiştir. Yaş Gluten oranı ise Glutomatik aleti ile ICC Standart No:137/1'de verilen yönteme göre iki tekrarlamalı ve ortalaması alınarak saptanmıştır. Düşme sayısı ise ICC-Standart No:107/1'e göre belirlenmiştir.

Çeşitlerin toplam antioksidan aktivitelerinin belirlenmesi amacıyla öncelikle çeşitlerin tam tane unları \%80'lik metanol çözeltisi kullanılarak ekstraksiyon işlemleri yapılmıştır. Elde edilen ekstraksiyonların antioksidan aktivite değerlerinin saptanması amacıyla DPPH serbest radikali kullanılmıştır. Hazırlanan örnekler spektrofotometrede $517 \quad \mathrm{~nm}$ 'de absorbans ölçümleri yapılarak çeşitlerin antioksidan aktiviteleri (\% inhibisyon) hesaplanmıştır (Brand-Williams et al. 1995; Ragaee ve ark. 2006).

Metiyonin ve sistin aminoasitlerinin miktarlarının saptanması amacıyla oksidasyon analizleri gerçekleştirilmiş olup her bir buğday çeşidine ait un örneklerinden 0.5 gram hassas terazide tartılarak 100 ml'lik cam şişelerin içerisine konulmuştur. 1 saat süreyle $30^{\circ} \mathrm{C}$ 'deki su banyosu içerisinde hazırlanan oksidasyon çözeltisinden $5 \mathrm{ml}\left(+4^{\circ} \mathrm{C}\right)$ örneklerin içerisine ilave edilmiştir. Daha sonra 24 saat süreyle buzdolabında bekletilmiştir. Süre sonunda oksidasyon reaksiyonu $0.9 \mathrm{~g}$ sodyumdisülfit ile durdurulmuştur. Standart ve her bir buğday örneğine ait aminoasit kompozisyonları ve miktarları Biochrom 20 Plus Aminoasit analiz cihazına enjekte edilerek Berlin Freie Üniversitesinde belirlenmiştir.

\section{Bulgular ve Tartışma}

Buğday tanesinde protein içeriği çeşit özelliğine, iklim ve toprak özelliklerine göre büyük varyasyonlar gösterebilmektedir bazı araştırıcılara göre buğday tanesinde protein içeriği \%8 ile \%18 (Christen 2009) arasında değişebilirken bazı kaynaklara göre buğday 
tanesinde protein içeriği \%25 (Gooding and Davies 1997) oranına kadar çıkabilmektedir. Çalışmamızda ele alınan buğday çeşitlerinde protein oranları büyük oranda varyasyon göstererek \%10.7 ile 18.7 arasında değişmiştir (Çizelge 1).

Tanede protein miktarı çevre şartlarından, yetiştirme tekniğinden ve çeşidin genetik özelliklerinden etkilenmektedir. Yüksek protein miktarına sahip buğday taneleri genelde daha sert bir tane yapısına sahip olup protein miktarından doğrudan etkilenen diğer kalite özelliklerini de olumlu yönde etkilemektedir.

Çizelge 1. Farklı ekmeklik buğday çeşitlerine ait protein ve nişasta oranları

Table 1. Protein and starch ratio of different bread wheat genotypes

\begin{tabular}{lcc}
\hline Çeşitler & $\begin{array}{c}\text { Protein oranı } \\
\text { (Kjeldahl, } \\
\text { Dumas, \%) }\end{array}$ & $\begin{array}{c}\text { Nişasta } \\
\text { (NIRS, \%) }\end{array}$ \\
\hline Ziyabey-98 & 11.3 & 64.3 \\
Gönen-98 & 13.0 & 62.6 \\
Basribey-95 & 10.7 & 64.1 \\
Cumhuriyet-75 & 11.5 & 64.4 \\
Golia & 11.2 & 65.2 \\
\hline İzmir-85 & 12.0 & 63.8 \\
Sagittario & 13.6 & 58.9 \\
Kıraç* & 18.7 & 57.0 \\
Osmaniyem* & 15.0 & 57.5 \\
Bezostaja* $_{\text {İzgi* }}^{*}$ & 17.3 & 56.4 \\
\hline
\end{tabular}

* Dumas yöntemiyle saptanmıştır.

*Obtained with Dumas method.

Yüksek protein miktarına sahip unlar yüksek somun hacimli, daha fazla su emilimi yapan ve daha iyi muhafaza edilebilen somunların üretimine önemli katkılar vermektedir. Protein oranın artması unun su alma ve hamurun kabarma potansiyelini arttırmaktadır. Dolayısıyla protein miktarı ekmek yapımında oldukça önemlidir. Buğday tanesinde protein oranın \%11-12'nin altında kalması istenilen özelliklerde ekmeğin oluşmamasına neden olmaktadır. Protein oranı \%11'in altında olan buğdaylar çoğunlukla tek başına ekmeklik yapımına uygun olmayıp ancak paçal yapımında değerlendirilebilen veya doğrudan yemlik olarak ayrılan buğdaylardır. Buğday çeşitlerin tanelerinde nişasta oranları \%56.4 ile \%65.2 arasında değişim göstermiştir. Nişasta oranların artan protein oranları ile genel olarak bir azalma gösterdiği saptanmıştır (Erekul ve ark. 2009). En düşük nişasta oranları en yüksek protein oranların ölçüldügü İzgi, Bezostaja ve Kıraç çeşitlerinde görülmüştür.

Protein oranın yanında ekmeklik buğday kalitesinin belirlenmesinde buğday unun su kaldırma oranı, gluten oranı, sedimentasyon miktarı ve düşme sayısı önemli özellikleri oluşturmaktadır. Çalışmamızda incelenen buğday çeşitlerin unun su kaldırma oranlarının çeşitlere bağlı olarak \%58.8 ile \%69.3 arasında değişerek genel olarak yüksek değerler verdiği saptanmıştır (Çizelge 2).

Buğday tane proteinin \%85'ini gluten oluşturmaktadır. Gluten ise gliadin ve glutenin protein fraksiyonlarından oluşmaktadır. Buğday çeşitlerine ait gluten oranları ise \%26.7 ile \%33.5 arasında değişerek genel olarak iyi değerler vermiştir. Özellikle Gönen-98 ve Golia çeşitlerin yaş gluten oranları diğer çeşitlerden daha iyi sonuçlara sahip olup yüksek değerler vermiştir. Yaş gluten sonuçlarına karşın sedimentasyon değerleri ekmek yapımı için yeterli ancak genel olarak orta seviyede kaldığı görülmektedir. Günümüzde kaliteli buğday çeşitlerinde sedimentasyon oranın $50 \mathrm{ml}$ ve üzerine çıkabileceği bilinmektedir (Christen, 2009). Sedimentasyon miktarı gluten kalitesi konusunda önemli bilgiler veren bir özelliktir. Daha önceki kalite özelliklerine göre bu özelliğin istenilen seviyelerde olmadığı söylenebilir. Önemli bir kalite parametresi olan sedimentasyon değerinin düşük çıkmasını bazı araştırıcılar tane dolum dönemindeki yüksek sıcaklıkların $\left(>30^{\circ} \mathrm{C}\right)$ gliadin miktarını artırması ile açıklamaktadırlar (Panozzo and Eagles 2000). Ege Bölgesi koşullarında yetiştirilen buğday çeşitlerinin sedimentasyon değerinin çoğu kez istenilen düzeye getirilememesi bu

Çizelge 2. Farklı ekmeklik buğday çeşitlerine ait bazı ekmeklik buğday kalite özellikleri

Table 2. Quality parameters of different bread wheat varieties

\begin{tabular}{lcccc}
\hline Çeşitler & $\begin{array}{c}\text { Unun su } \\
\text { kaldırma oranı (\%) }\end{array}$ & $\begin{array}{c}\text { Gluten } \\
\text { oranı (\%) }\end{array}$ & $\begin{array}{c}\text { Sedimentasyon } \\
\text { miktarı (ml) }\end{array}$ & $\begin{array}{c}\text { Düşme } \\
\text { sayısı (s) }\end{array}$ \\
\hline Ziyabey-98 & 65.2 & 28.7 & 19 & 377 \\
Gönen-98 & 69.3 & 33.2 & 31 & 283 \\
Basribey-95 & 63.9 & 31.4 & 20 & 364 \\
Cumhuriyet-75 & 58.8 & 29.1 & 25 & 404 \\
Golia & 65.6 & 33.5 & 20 & 402 \\
Izmir-85 & 61.4 & 26.7 & 24 & 389 \\
\hline
\end{tabular}


nedenden kaynaklanıyor olabilir. Ekmeklik kalitesi üzerine etki eden önemli özelliklerden birisi de düşme sayısıdır. Ekmeklik unlarda aranan düşme sayısı değeri $250 \pm 25$ saniyedir (Erekul ve ark. 2009). Düşme sayısının bu değerin altında veya üstünde olması unda alfa amilaz enzim aktivitesini ve böylece ekmeğin bünyesini olumsuz yönde etkilemektedir. Ekmeklik kalitesi üzerine etki eden bu özelliğin diğer özelliklerden ayıran en önemli farkı düşme sayısının en çok iklim koşullarından etkilenmesidir (Gooding et al. 2003). Özellikle tane dolum döneminde meydana gelen kurak ve sıcak hava periyotları düşme sayısının hızla yükselmesine ve undaki enzim aktivitesinin hızla düşmesine ve ekmeğin istenilen düzeyde kabarmamasına neden olmaktadır. Bizim çalışmamızda aynı yıl yetiştirilen buğday çeşitlerinde düşme sayıları 283 ile 404 s arasında değişim göstererek optimum seviyelerin üzerinde kalmıştır. Gönen-98 çeşidi hariç denemede yer alan diğer çeşitlerin düşme sayıları yüksek olup, bu çeşitlerden elde edilen unların alfa amilaz aktiviteleri düşük seviyede bulunmuştur.

Buğday ve ürünlerinin sadece insanların beslenmesindeki yeri ve önemi değil, buğday tanelerinin içerdikleri insan sağlığına katkıda bulunan ve korunmasına yardımcı olan yaralı maddeler nedeniyle de birçok hastalık riskini azaltıcı ve önleyici etkilerinin bulunduğu bilinmektedir (Ryan et al. 2011). Son yıllarda bu hastalıklara yakalanma risklerini azaltıcı, insan sağlığını koruyucu fenolik madde ve antioksidan içerikli gıdalardan bahsedilmektedir. Buğdayın içerdiği fitokimyasal maddeler nedeniyle doğal besinsel antioksidan kaynağıdır ve bu aktif bileşikler güçlü antioksidan aktiviteleri ile insan ve hayvanlarda birçok kronik rahatsızlığı önler veya ilerlemesini geciktirebilmektedir (Menteş-Yılmaz 2011). Ülkemizin farklı coğrafik bölgelerinden temin edilen 45 adet ekmeklik buğday çeşitlerine ait antioksidan aktivitelerine yönelik analizlerde antioksidan aktivite bakımından çeşitlerin \%11.89 ile \%26.33 arasında önemli farklılıklar ortaya koyduğu saptanmıştır. (Çizelge3).

Çeşitlere ait sonuçlar incelendiğinde en yüksek antioksidan aktiviteye \%26.33 ile Tosunbey çeşidi ulaşırken, en düşük ortalama Doğankent çeşidinde elde edilmiştir

Çeşitlerin antioksidan aktivite bakımından önemli farklılıklar gösterdiği ve bazı çeşitlerin antioksidan aktivite bakımından yüksek potansiyele sahip olduğu belirlenmiştir. İnsan
Çizelge 3. Tosunbey ve Doğankent ekmeklik buğday çeşitlerine ait antioksidan aktivite değerleri

Table 3. Total antioxidant activities of Tosunbey and Doğankent bread wheat varieties

\begin{tabular}{lc}
\hline Çeşitler & $\begin{array}{c}\text { Antioksidan aktivite } \\
\text { (\% inhibisyon) }\end{array}$ \\
\hline Doğankent & 11.89 \\
Tosunbey & 26.33 \\
\hline
\end{tabular}

vücudumuzun yaklaşık \%20'sini proteinler meydana getirmektedir. Aminoasitlerin yapıtaşı olduğu proteinler vücudun neredeyse tüm biyolojik faaliyetlerinde aktif olarak rol almaktadırlar. Esansiyel aminoasitlerden biri olan metiyonin en önemli özelliklerden biri metabolizma ve büyüme için gerekli olan kükürt ve diğer bileşiklerin kaynağını oluşturmaktadır. 45 adet ekmeklik buğday çeşitlerine yönelik metiyonin aminoasidi içeriği incelendiğinde çeşitler arası önemli farklıkların olduğu ve metiyonin içeriklerinin $0.217 \mathrm{~g} / 100 \mathrm{~g}$ ile $0.374 \mathrm{~g} / 100 \mathrm{~g}$ arasında değişim gösterdiği saptanmıştır. En düşük metiyonin içeriği Seri 82 çeşidinde bulunurken en yüksek değer ise İzgi çeşidinde bulunmuştur (Çizelge 4).

Diğer önemli bir aminoasit olan sistin aminoasidi prematüre bebekler, yaşlılar, metabolik rahatsızlığı olanlar ve emilim bozukluğu yaşayanlar için günlük beslenme ile karşılanması gereken aminoasitlerden birisidir. Sistin aminoasidi antioksidan gibi hareket ederek radyasyon ve kirliliğin zararlı etkilerinden vücudumuzu korumaktadır. Tüm antioksidanlar

Çizelge 4. Seri 82 ve İzgi ekmeklik buğday çeşitlerine ait metiyonin aminoasit içeriğine ait değerlerler

Table 4. Methionine aminoacid contents of Seri82 and Izgi bread wheat varieties

\begin{tabular}{lc}
\hline Çeşitler & $\begin{array}{c}\text { Metiyonin } \\
\text { (g/100g un) }\end{array}$ \\
\hline Seri 82 & 0.217 \\
İzgi & 0.374 \\
\hline
\end{tabular}

Çizelge 5. Seri 82 ve İzgi ekmeklik buğday çeşitlerine ait sistin aminoasit içeriğine ait değerlerler

Table 5. Cystine aminoacid contents of Seri 82 and Izgi bread wheat varieties

\begin{tabular}{ll}
\hline Çeşitler & \multicolumn{1}{c}{$\begin{array}{c}\text { Sistin } \\
\text { (g/100g un) }\end{array}$} \\
\hline İzgi & 0.706 \\
Kıraç & 0.706 \\
Momtchill & 0.494 \\
\hline
\end{tabular}

gibi yaşlanmayı geciktirerek, serbest radikalleri ve toksinleri etkisiz hale getirmede etkili olmaktadır. Ayrıca sistin vücudumuzda karaciğer, böbrek ve kemik iliği yapımında bulunur. Yine aynı 45 adet ekmeklik buğday 
çeşitlerine yönelik sistin aminoasidi içeriği incelendiğinde çeşitler arası önemli farklıkların olduğu ve sistin içeriklerinin $0.706 \mathrm{~g} / 100 \mathrm{~g}$ ile $0.494 \mathrm{~g} / 100 \mathrm{~g}$ arasında değişim gösterdiği saptanmıştır. En düşük sistin içeriği Momtchill çeşidinde bulunurken en yüksek değerler ise İzgi ve Kıraç çeşitlerinde bulunmuştur (Çizelge 4).

\section{Sonuç}

Bildirimizde sadece iki aminoaside ait ülkemizde yaygın olarak yetiştirilen ve çok sayıda ekmeklik buğday çeşitlerine ait aminoasit spektrumu ve miktarlarına ait kısa bir özet sunulmuştur. Yapılan çalışmalar ile ekmeklik kalite özellikleri, antioksidan aktivite ve aminoasit içerikleri bazında ülkemizde ekilen ekmeklik buğday çeşitlerine ait çok fazla sonuçların bulunmaması nedeniyle sağlık ve beslenme açısından büyük önemi bulunan bu özelliklere ait bazı özet sonuçların temel veriler oluşturarak literatüre kazandırıması ve ekmeklik buğday çeşitlerin gelecek ıslah çalışmalarında göz önünde bulundurulması amaçlanmıştır.

\section{Kaynaklar}

Anjum F.M., Ahmad I., Butt M.S., Sheikh M.A. and Pasha I., 2005. Amino acid composition of spring wheats and losses of lysine during chapati baking. J. of Food Composition and Analysis, 18: 523-532

Brand-Williams W., Cuvelier M.E. and Berset C., 1995. Use of radical method to evaluate antioxidant activity. Lebensm. Wiss. $u$. Technology-Food Science and Technology, 28 (1): $25-30$
Christen O., 2009. Winterweizen, das Handbuch für Profis, 383 sayfa, DLG Verlag, Frankfurt, Almanya

Gooding M.J. and Davies W.P., 1997. Wheat Production and Utilization. CAB International, Wallingford, UK

Gooding M.J., Smith G., Davies W.P. and Kettlewell P.S., 2003. The Use of Residual Maximum Likelihood to Model Grain Quality Characteristics of Wheat With Variety, Climatic and Nitrogen Fertilizer Effects. J. Agric. Sci., 128: 135-142

Erekul O., Kautz T., Ellmer F. and Turgut I., 2009. Yield and bread making quality of different wheat (Triticum aestivum L.) genotypes grown in western Turkey. Arch. Agron. Soil Science, 55: 169-182

Menteş-Yılmaz Ö, 2011. Türkiye'de Yetiştirilen Başlıca Buğday Çeşitlerinin Antioksidan Aktivitelerinin ve Fenolik Asit Dağılımlarının Belirlenmesi Ve Ekmeğin Nar Kabuğu Ekstraktı ,le Zenginleştirilmesi. (Doktora Tezi). Ankara Üniversitesi Fen Bilimleri Enstitüsü, s. 89

Panozzo J.F. and Eagles H.A., 2000. Cultivar and environmental effects on quality characters in wheat. Australian Journal of Agricultural Research, 51: 629-636

Ragaee S., Abdel-Aal E.M. and Noaman M., 2006. Antioxidant activity and nutrient composition of selected cereals for food use. Food Chemistry, 98: 32-38

Ryan L., Thondre P.S. and Henry C.J.K., 2011. OatBased breakfast cereals are a rich source at polyphenols and high in antioxidant potential. J. of Food Composition and Analysis, 24: 929-9 